\title{
PROCESSO DE VACINAÇÃO CONTRA FEBRE AFTOSA EM BOVINOS: UMA EXPERIÊNCIA DA PRÁTICA DE MANEJO
}

\section{PROCESS OF VACCINATION AGAINST FOOT-AND-MOUTH DISEASE IN BOVINE: A EXPERIENCE OF MANAGEMENT PRACTICE}

\section{Adalberto Francisco da Silva Júnior ${ }^{1}$; Andréa Renilda Silva Soares ${ }^{2}$;Elisiane Martins de Lima ${ }^{3}$; Joanna Rafaella da Silva ${ }^{4}$ Ivalda de Albuquerque Lima ${ }^{5}$}

DOI: $\underline{\text { https://doi.org/10.31692/978-65-991061-7-0.496-497 }}$

\section{INTRODUÇÃO}

O processo de vacinação consiste na aplicação da dose por via subcutânea (embaixo da pele dos animais). A dose a ser aplicada em cada animal é indicada no rótulo da vacina. É uma prática realizada em rebanhos para prevenção da febre aftosa, doença viral, que é altamente contagiosa e de fácil disseminação, ou seja água, ar, alimentos, objetos e ambientes contaminados podem transmitir a doença; que afeta os bovinos além de outros animais que possuem cascos fendidos, causando sintomas como aftas na boca e na gengiva, feridas entre as unhas e nas mamas. $\mathrm{O}$ animal apresenta febre muito alta, perda de peso, dificuldade para ingerir alimentos e produzir o leite. Além de provocar perdas na produção e barreiras comerciais dos animais e seus subprodutos, principalmente ao embargo comercial da carne.

Essa prática é recorrente na produção bovina. Isso se dá porque a doença compromete a produção;a vacinação é obrigatória para bovinos e bulalinos, imprescindível para a erradicação da doença, conforme a legislação, onde o Ministério da Agricultura Pecuária e Abastecimento (MAPA) criou o Programa Nacional de Erradicação e Prevenção da Febre Aftosa (PNEFA). As campanhas de vacinação da febre aftosa contribuem com o controle dadoença e processo erradicação, além de garantir a saúde do rebanho.

\section{RELATO DE EXPERIÊNCIA}

O processo de vacinação ocorreu durante as aulas da disciplina de Bovinocultura de corte e leite, disciplina pertinente ao curso de Bacharelado em Agronomia do IFPE-Campus Vitória de Santo Antão. A atividade foi realizada nos animais jovens e adultos. Antes de

\footnotetext{
${ }^{1}$ Bacharelado em Agronomia, Universidade Federal Rural de Pernambuco, adalbertofrancisco75@gmail.com

2 Bacharelado em Agronomia, Instituto Federal de Pernambuco Campus Vitória de Santo Antão, andrearenildaagronomia@gmail.com

3 Mestrado em Produção Agrícola, Universidade Rural de Pernambuco/ Unidade Acadêmica de Garanhuns, elisiane.ane@gmail.com

${ }^{4}$ Bacharelado em Agronomia, Instituto Federal de Pernambuco Campus Vitória de Santo Antão, raffaelly_hta@hotmail.com

${ }^{5}$ Professora Doutora, Instituto Federal de Pernambuco Campus Vitória de Santo Antão, ivalda.lima@ vitoria.ifpe.edu.br
} 
iniciar o processo propriamente dito organizou-se os equipamentos e utensílios necessários e verificou-se suas condições. Sendo utilizado nessa prática uma pistola de vacinação esterilizada, caixa térmica, com gelo para manter a vacina em temperatura adequada. Mediante confirmação de bom estado iniciou-se o processo. Foi realizada aaveriguação da pistola de aplicação, da temperatura do armazenamento e dose recomendada no rótulo das vacinas. O procedimento utilizado para a vacinação iniciou-se com a separação e contenção dos bovinos, com a ajuda do vaqueiro;para cada aluno, um animal. Em seguidafoi adicionada a dose de $5 \mathrm{ml}$ da vacina na pistola de aplicação, utilizou-se agulhas não muito grossas. A aplicação se deu na tábua do pescoço embaixo da pele dos animais. As medidaspreventivas da doença e o acompanhamento do período de vacinação pode evitar que haja prejuízos econômicos e perdas da produção. É de grande importância sempre promover o bem- estar animal partindo dos príncipios, como sanidade, mantendo os animais livres da doença.

Imagem 1: Processo de Aplicação. Fonte: Própria

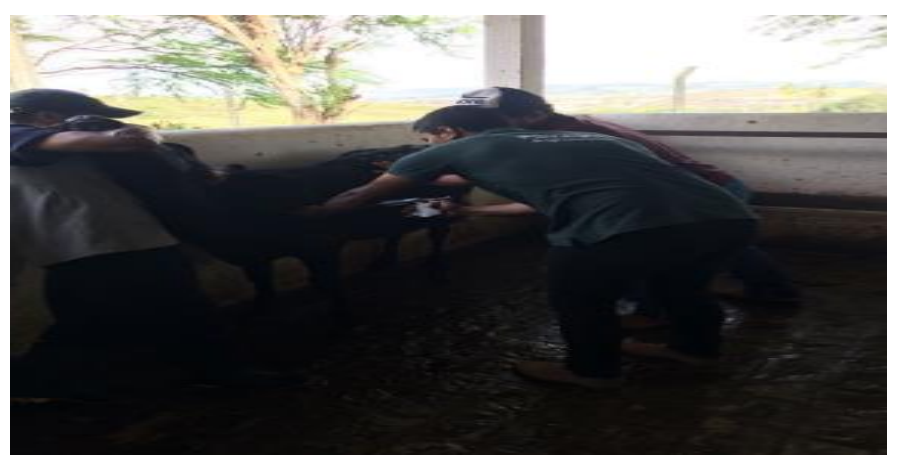

\section{CONSIDERAÇÕES}

A experiência vivenciada da atividade foi fundamental na formação dos participantes uma vez que estes obtiveram a possibilidade de colocar em prática os conhecimentos teóricos adquiridos na sala de aula e confronta-los com a realidade da prática zootécnica.

\section{REFERÊNCIAS}

TRECENTI, Anelize. Febre Aftosa. Revista Científica Eletrônica de medicina veterinária. Editora FAEP, Garça-SP, No 21, pág. 1-7, julho de 2013.

Informativo Técnico. Vacinação contra Febre Aftosa 2017. Coordenadoria de Defesa Agropecuária - CDA. Programa Estadual de Erradicação da Febre Aftosa. São Paulo, p. 4. maio 2017.

Governo do Estado de Pernambuco. Febre Aftosa. Disponível em $:<$ http://www.adagro.pe.go v.br/web/adagro/aftosa>. Acessado em 08 de setembro de 2018.

Agricultura. Febre Aftosa. Disponível em $:<$ http://www.agricultura.gov.br/assuntos/sanidade -animal-e-vegetal/saude-animal/programas-de-saude-ani mal/febre-aftosa $>$. Acessado em 08 de setembro de 2018. 